\title{
ARTIGOS
}

\section{A FIELD STUDY OF PROTEINURIA IN INDIVIDUALS INFECTED WITH SCHISTOSOMA MANSONI}

\author{
José Carlos Bina1, Zilton A. Andrade ${ }^{1}$, Reynaldo Dietze ${ }^{2}$ and \\ Aluízio Prata2
}

\begin{abstract}
Proteinuria was detected in $24.7 \%$ of 89 individuals with hepatosplenic schistosomiasis and in only $4.6 \%$ of 86 subjects with mild hepato-intestinal schistosomiasis, all of them living in comparable conditions in two endemic areas in Bahia, Brazil. From nine individuals who had proteinuria over $30 \mathrm{mg} / 100 \mathrm{ml}$, eight had hepatosplenic schistosomiasis. These findings may be related to the presence of schistosomal nephropathy and reveal the significance of this condition in the field in endemic areas of schistosomiasis.
\end{abstract}

Key words: Schistosoma mansoni. Proteinuria. Field study. Schistosomal nephropathy.

It has been documented that renal lesions appear to be associated with hepatosplenic schistosomiasis mansoni in $\operatorname{man}^{12} 23$. There are many types of glomerular changes present but usually they are represented by chronic diffuse membrano-proliferative glomerulonephritis with lobular accentuation, and the nephrotic syndrome is the main form of clinical presentation 61516 . Schistosomal antigens and several classes of immunoglobulins and complement have been detected in the glomerular lesions both in humans 811 and in experimental animals 471214 . Therefore, this feature of hepatosplenic schistosomiasis is considered a good example of immunocomplex disease produced by a parasitic infection. However, the clinical significance of renal involvement in subjects living in endemic areas, as opposed to hospitalized patients, has not been determined. The only previous attempt was that of Lehman et al 10 .

The present study represents an attempt to investigate the significance of proteinuria in infected people living in two endemic areas of schistosomiasis in Bahia, Brazil.

\section{MATERIAL AND METHODS}

This study involved the quantitative estimation of proteinuria and arterial blood pressure from 175 individuals living in Taquarendi and Caatinga do

Supported by CNPq, project PIDE V, process no $3651 / 82$.

1. Centro de Pesquisas Gonçalo Moniz (FIOCRUZ/UFBa), Salvador - BA.

2. Núcleo de Medicina Tropical e Nutrição, Universidade de Brasilia, Brasilia, Brasil.

Recebido para publicação em 29/8/1984.
Moura, Bahia-Brazil, two highly endemic areas of schistosomiasis. These individuals were all included in a longitudinal study and have been observed during several years. The majority have been treated, but reinfection seems to occur frequently. All the subjects were infected with $S$. mansoni as determined by fecal examination performed by a quantitative method ${ }^{9}$. Following the criteria of Prata and Bina ${ }^{13}$ for the clinical classification of schistosomiasis, subjects were divided into two groups: a) hepatointestinal group with 86 cases, and b) hepatosplenic group with 89 cases. All the patients with hepatosplenic schistosomiasis were included in the study. They showed an enlarged, sometimes nodular and hard liver, with prominent hypertrophy of the left lobe, and splenomegaly. Actually, some of them have had splenectomy in the past. For the purpose of the present study the hepatointestinal (mild, usually assymptomatic infection) and hepatosplenic cases were paired whenever possible by age, sex and preferentially included those individuals from the same family or living in the same house. For the determination of proteinuria, urine was collected in clean glass bottles, and tested immediately by Labstix (Ames Co.), at the time the patients were clinically reexamined. All the individuals examined were performing their usual work routine, only had mild, vague complaints, and at clinical examination did not seem to have any major associated diseases. Results of proteinuria were quantitatively expressed as "traces", $30,100,300$ and above $2,000 \mathrm{mg}$ per $100 \mathrm{ml}$.

Arterial blood pressure was taken by the usual sphygmomanometer method with the subject seated. Values above $140 \times 90 \mathrm{mmHg}$ were considered as hypertension. 
Bina JC, Andrade $Z A$, Dietze R, Prata A. A field study of proteinuria in individuals infected with Schistosoma mansoni Revista da Sociedade Brasileira de Medicina Tropical 18: 7-10, Jan-Mar, 1985

\section{RESULTS}

Age and sex of the individuals studied appear in Table 1 . The youngest was 9 years old and the two groups considered are shown in Table 2 . The total prevalence of proteinuria reached $14.8 \%$, with $24.7 \%$ for hepatosplenic and $4.6 \%$ for the hepato-intestinal cases $\left(X^{2}=13.41<0.001\right)$, with no difference due to sex. Of the 26 individuals with proteinuria, 9 of them could be considered to have striking proteinuria (above
$30 \mathrm{mg} / 100 \mathrm{ml}$ ), and only one of the latter did not belong to the hepatosplenic group. The prevalence of arterial hypertension was $22.2 \%(39 / 175)$. Among the hypertensive subjects with proteinuria, $6.2 \%$ belonged to the hepato-intestinal group and $26.0 \%$ to the hepatosplenic group, as can observed in Table 3 . It can also be observed that from the 39 subjects showing high blood pressure only 7 of them (17.9\%) presented proteinuria.

Table 1 - Age and sex of 175 cases of schistosomiasis presented in this study

\begin{tabular}{cccccccc}
\hline \multirow{2}{*}{$\begin{array}{c}\text { Age } \\
\text { (years) }\end{array}$} & \multicolumn{9}{c}{ Sex } \\
\cline { 2 - 8 } & case & control & case & control & No & Total \\
\hline$<$ & 6 & 9 & 6 & 8 & 29 & $(16,6)$ \\
$20-29$ & 6 & 13 & 5 & 6 & 30 & $(17,1)$ \\
$30-39$ & 10 & 8 & 11 & 12 & 41 & $(23,5)$ \\
$40-49$ & 5 & 9 & 14 & 6 & 34 & $(19,4)$ \\
$50-59$ & 5 & 8 & 17 & 1 & 31 & $(17,7)$ \\
60 or over & 2 & 2 & 3 & 3 & 10 & $(5,7)$ \\
\hline Total & 34 & 49 & 56 & 36 & 175 & $(100,0)$ \\
\hline
\end{tabular}

Table 2-Prevalence of proteinuria according to clinical forms of schistosomiasis

\begin{tabular}{lccccc}
\hline \multirow{2}{*}{$\begin{array}{l}\text { Clinical } \\
\text { forms }\end{array}$} & \multirow{N}{*}{} & \multicolumn{4}{c}{ Proteinuria } \\
\cline { 3 - 6 } & Cases & Positive & $(\%)$ & Negative & (\%) \\
\hline Hepato-intestinal & 86 & 4 & $(4.6)$ & 82 & $(95.4)$ \\
Hepatosplenic & 89 & 22 & $(24.7)$ & 67 & $(75.3)$ \\
\hline Total & 175 & 26 & $(14.8)$ & 149 & $(85.2)$ \\
\hline
\end{tabular}

$X^{2}=13.91<0.001$

The egg-load varied from 24 to 9,120 eggs per gram of feces, and did not seem to correlate with the presence or degree of proteinuria, as can be observed in Table 4. It can be noted that all people with proteinuria had less than 500 eggs per gram of feces.

Table 3-Prevalence of proteinuria in cases of schistosomiasis in relation to clinical forms and the presence of arterial hypertension

\begin{tabular}{|c|c|c|c|c|c|c|c|c|c|c|c|c|}
\hline \multirow{3}{*}{$\begin{array}{l}\text { Clinical } \\
\text { forms }\end{array}$} & \multicolumn{6}{|c|}{ Hypertension } & \multicolumn{6}{|c|}{ No hypertension } \\
\hline & \multicolumn{2}{|c|}{ proteinuria } & \multicolumn{2}{|c|}{$\begin{array}{c}\text { no } \\
\text { proteinuria }\end{array}$} & \multicolumn{2}{|c|}{ Total } & \multicolumn{2}{|c|}{ proteinuria } & \multicolumn{2}{|c|}{$\begin{array}{c}\text { no } \\
\text { proteinuria }\end{array}$} & \multicolumn{2}{|c|}{ Total } \\
\hline & $N^{o}$ & $(\%)$ & No & $(\%)$ & N.o & $(\%)$ & $N o$ & $(\%)$ & $N o$ & $(\%)$ & Noo & (\%) \\
\hline Hepato-intestinal & 1 & $(6.2)$ & 15 & $(93.8)$ & 16 & $(100.0)$ & 3 & $(4.3)$ & 67 & $(95.7)$ & 70 & $(100.0)$ \\
\hline Hepatosplenic & 6 & $(26.0)$ & 17 & $(74.0)$ & 23 & $(100.0)$ & 16 & $(24.3)$ & 50 & $(75.7)$ & 66 & $(100.0)$ \\
\hline Total & 7 & $(17.9)$ & 32 & $(82.1)$ & 39 & $(100.0)$ & 19 & $(13.9)$ & 117 & $(86.1)$ & 136 & $(100.0)$ \\
\hline
\end{tabular}


Bina JC, Andrade ZA, Dietze R, Prata A. A field study of proteinuria in individuals infected with Schistosoma mansoni. Revista da Sociedade Brasileira de Medicina Tropical 18: 7-10, Jan-Mar, 1985

Table 4-Prevalence of proteinuria in relation to fecal egg-load in 175 subjects with schistosomiasis

\begin{tabular}{lccccc}
\hline \multirow{2}{*}{ Proteinuria } & \multicolumn{4}{c}{ No eggs per gram of feces } & \multirow{2}{*}{ Total } \\
\cline { 2 - 5 } & not done & $<500$ & $500-1000$ & $>1000$ & \\
\hline Present & 2 & 24 & 0 & 0 & 26 \\
Absent & 10 & 121 & 11 & 7 & 149 \\
\hline Total & 12 & 145 & 11 & 7 & 175 \\
\hline
\end{tabular}

\section{DISCUSSION}

Proteinuria, but not arterial hypertension, was found in the present study to be more prevalent in hepatosplenic than in mild or asymptomatic schistosomiasis. These findings are apparently in disagreement with those of Lehman et al ${ }^{10}$ who found no correlation between proteinuria and splenomegaly in subjects infected with $S$. mansoni and living in the field. However, they found an incidence of $35.4 \%$ of people with splenomegaly in their series. This is well above the usual $4-6 \%$ incidence of hepatosplenic schistosomiasis observed in endemic areas of $\mathrm{Brazil}^{5}$ and probably indicates that not all cases of splenomegaly included in the study of Lehman et al ${ }^{10}$ represented hepatosplenic schistosomiasis. This is an important point, because schistosomal glomerulopathy seems to be restricted to patients with hepatosplenic schistosomiasis 15 . Apparently portal hypertension and the consequent collateral circulation are critical changes that serve to divert antigens, and/or immunocomplexes, generated in the portal system, from the Kupffer cell filter to the kidneys ${ }^{18} 19$.

The prevalence of proteinuria found in this field study amongst hepatosplenic cases was $24.7 \%$ which is more impressive than the $15.0 \%$ of renal disease present in patients with hepatosplenic schistosomiasis seen in our hospitals 15 or the $12.0 \%$ incidence of chronic glomerulonephritis observed in autopsied cases $^{2}$. Our study is therefore in keeping with the concept of schistosomal nephropathy and shows that renal involvement could be an important feature to be considered in hepatosplenic schistosomiasis in the endemic areas. Although proteinuria defined as "traces" may not be significant, a clear cut difference of its prevalence was seen for the two groups. It represents values from 10 to $15 \mathrm{mg}$ per $100 \mathrm{ml}$ and can be considered as the upper physiological limits according to Souza et al 17 , who studied the elimination of urinary protein in Brazilians. However when we consider expressive proteinuria (above $30 \mathrm{mg} / 100 \mathrm{ml}$ ) the dif- ference between hepatosplenic to hepato-intestinal schistosomiasis becomes striking, despite the small number of cases considered.

From our own experience, arterial hypertension seems to be a frequent occurrence in people living in the interior of the state of Bahia, Brazil. Its causes and signficance needs investigation. It did not correlate. with hepatosplenic schistosomiasis in this present study, although one single blood pressure determination is not an adequate method to completely exclude this condition.

\section{RESUMO}

Proteinúria foi detectada em $24,7 \%$ de 89 pacientes com a forma hepatoesplênica da esquistossomose e em apenas 4,6\% de 86 pacientes com a forma hepatointestinal dessa parasitose. Todos os pacientes viviam em condiçôes epidemiológicas semelhantes em duas áreas endêmicas da Bahia, Brasil. Dos nove individuos que tinham proteinúria acima de $30 \mathrm{mg} / 100 \mathrm{ml}$, oito tinham a forma hepatoesplênica da doença. Estes achados podem estar relacionados à presença de uma glomerulopatia esquistossomótica e mostra o significado desta condição no campo, em áreas endêmicas de esquistossomose.

Palavras chaves: Schistosoma mansoni. Proteinúria. Estudo de campo. Nefropatia esquistossomótica.

\section{REFERENCES}

1. Andrade ZA, Andrade SG, Sadigursky M. Renal changes in patients with hepatosplenic schistosomiasis. American Journal of Tropical Medicine and Hygiene 20:77-83, 1971 .

2. Andrade ZA, Queiroz AC. Lesões renais na esquistos- 
Bina JC, Andrade ZA, Dietze R, Prata A. A field study of proteinuria in individuals infected with Schistosoma mansoni. Revista da Sociedade Brasileira de Medicina Tropical 18: 7-10, Jan-Mar, 1985

somose hepatosplênica. Revista do Instituto de Medicina Tropical de São Paulo 10:36-40, 1968.

3. Andrade ZA, Rocha H. Schistosomal glomerulopathy. Kidney International 16:23-29, 1970.

-

4. Andrade ZA, Susin M. Renal changes in mice infected with Schistosoma mansoni. American Journal of Tropical Medicine and Hygiene 23:400-403, 1974.

5. Barbosa FS. Epidemiologia. In: Cunha AS (Ed) Esquistossomose mansoni. Sarvier Editora, São Paulo, p. $31-59,1970$.

6. Brito T, Gunji J, Camargo ME, Penna DO, Silva LC. Advanced kidney disease in patients with hepatosplenic Manson's schistosomiasis. Revista do Instituto de Medicina Tropical de São Paulo 12:225-235, 1970.

7. Cavalo T, Galvanek EC, Ward PA, von Lichtenberg F. The nephropathy of experimental hepatosplenic schistosomiasis. American Journal of Pathology 76:433-445, 1974.

8. Hoshino AO, Shimizu S, Brito T, Kanamura HY, Canto AL, Silva AO, Campos AR, Penna DO, Silva LC. Human Schistosomiasis: Schistosoma mansoni antigen detection in renal glomeruli. Transactions of the Royal Society of Tropical Medicine and Hygiene 70:492-496, 1976.

9. Katz N, Chaves A, Pellegrino J. A simple device for quantitative stool thick-smear technique in schistosomiasis mansoni. Revista do Instituto de Medicina Tropical de São Paulo 14:397-400, 1972.

10. Lehman JS, Mott KE, Souza CAM, Leboreiro O, Muniz TM. The association of schistosomiasis mansoni and proteinuria in an endemic area. American Journal of Tropical Medicine and Hygiene 24:616-618, 1975.
11. Moriearty PL, Brito E. Elution of renal antischistosome antibodies in human schistosomiasis mansoni. American Journal of Tropical Medicine and Hygiene 26:717-722, 1977.

12. Natali G, Cioli D. Immune - complex nephritis in Schistosoma mansoni infected mice. European Journal of Immunology 6:359-364, 1976.

13. Prata A, Bina JC. Development of hepatosplenic form of schistosomiasis. Gazeta Medica da Bahia 68:49-60, 1968.

14. Robinson A, Lewert RM, Spargo BH. Immune - complex glomerulonephritis and amyloidosis in Schistosoma japonicum infected rabbits. Transactions of the Royal Society of Tropical Medicine 76:214-226, 1982.

15. Rocha H, Cruz T, Brito E, Susin M. Renal involvement in patients with hepatosplenic schistosomiasis mansoni. American Journal of Tropical Medicine and Hygiene 25:108-115, 1976.

16. Silva LC, Brito T, Camargo ME, Boni DR, Lopes JD, Gunji J. Kidney biopsy in hepatosplenic form of infection with Schistosoma mansoni in man. Bulletin of the World Health Organization 42:907-910, 1970.

17. Souza CAM, Lessa I, Leboreiro O. Concentração de proteínas na urina de individuos normais. Revista de Saúde Pública de São Paulo 7:405-408, 1973.

18. Van Marck E. Presence of the circulating polysaccharide antigen in the liver of mice infected with Schistosoma mansoni. Annee de la Societé Belge de Médicine Tropicale 55:373-377, 1975 .

19. Van Marck E, Deelder AM, Gigase PLJ. Effect of partial portal vein ligation on immune glomerular deposits in Schistosoma mansoni infected mice. British Journal of Experimental Pathology 58:412-417, 1977. 